\title{
Minireview
}

nephron

Clinical

Practice

Published online: December 3, 2013

DOI: $\underline{10.1159 / 000356394}$

\section{Potential for Biomarkers of Chronic Kidney Disease-Mineral Bone Disorder to Improve Patient Care}

\author{
H.V. Alderson J.P. Ritchie D. Green D. Chiu P.A. Kalra \\ Vascular Research Group, Department of Renal Medicine, Salford Royal NHS Foundation Trust, \\ Manchester Academic Health Sciences Centre, The University of Manchester, Salford, UK
}

\section{Key Words}

Arterial calcification · Chronic kidney disease $\cdot$ CKD-MBD

biomarkers - Improving patient care $\cdot$ Mineral bone

disorder - Vascular risk - Vascular stiffness

\begin{abstract}
Chronic kidney disease (CKD) is a growing public health problem. Cardiovascular disease is common in CKD, but standard risk assessment tools perform poorly in this population. Equally, despite CKD being associated with an increased risk for death and dialysis, standard biochemical measurements have limited prognostic value. Novel serum biomarkers may aid risk assessment; however, studies have shown varying clinical utility in relation to progression of CKD, incident cardiovascular disease and death. This inconsistency may relate to limitations in our understanding of the biological actions and interactions of these biomarkers. This review discusses a range of biomarkers in relation to these clinical endpoints in CKD-mineral bone disorder. We consider where biomarkers may enhance risk stratification and improve clinical management, but also highlight where they fall short of achieving this objective.

(c) 2013 S. Karger AG, Basel
\end{abstract}

\section{Cardiovascular Disease in Chronic Kidney Disease versus the General Population}

Chronic kidney disease (CKD) is an important public health problem, affecting around $10 \%$ of the UK adult population [1]. Cardiovascular disease is common among patients with CKD and is the most common cause of death in this population $[2,3]$.

Standard cardiovascular risk factors such as diabetes, hypertension and dyslipidaemia are common in CKD. However, these are not the only determinants of the high rates of cardiovascular disease associated with $\mathrm{CKD}$, other factors include endothelial dysfunction, inflammation, arterial calcification and oxidative stress $[1,4-10]$. The relative importance and interdependence of each of these factors in determining cardiovascular risk in CKD is largely unknown.

\section{CKD-Mineral Bone Disorder and Vascular Risk}

The CKD-mineral bone disorder (CKD-MBD) axis associates with abnormalities of bone, altered bone turnover and arterial calcification [11]. Arterial calcification results in reduced arterial elasticity, increased left ventricular afterload, left ventricular hypertrophy $(\mathrm{LVH})$ and reduced 


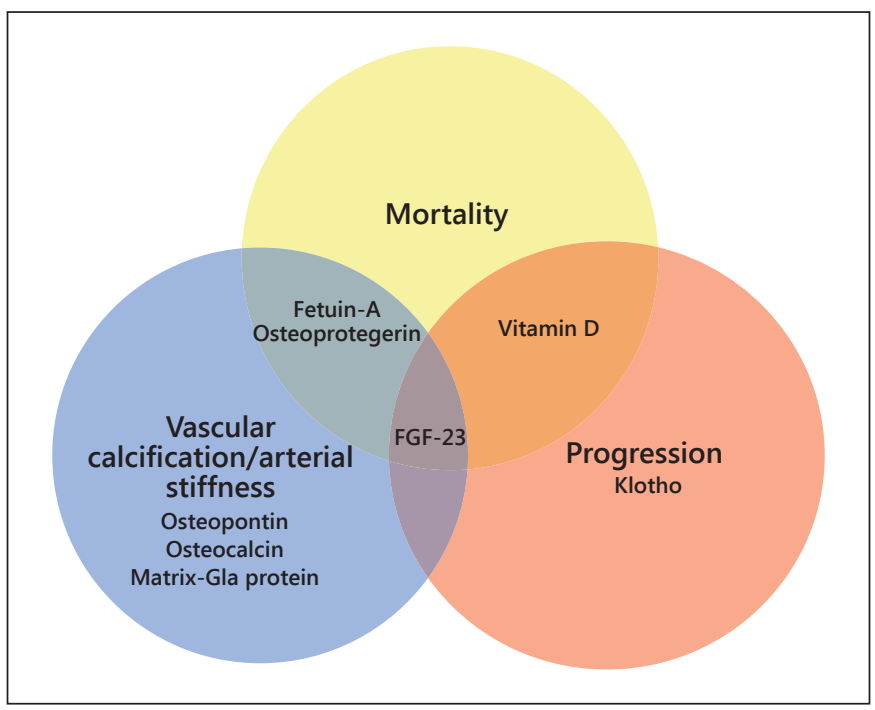

Fig. 1. Relationship between biomarkers and clinical endpoints in CKD-MBD.

coronary blood flow [12]. Increased arterial calcification is an independent predictor of cardiovascular mortality [4]. Although not all patients are affected equally, it can occur early in the evolution of CKD and progresses with declining glomerular filtration rate (GFR) $[10,13,14]$.

Elevated levels of calcium phosphate product is a hallmark of arterial calcification $[6,15,16]$, but is a relatively late marker. Imaging techniques such as computerized tomography (CT) or ultrasound scanning are able to detect arterial calcification but are unable to differentiate whether this is the intimal deposition seen in traditional atherosclerotic changes or the medial calcification observed with increased vascular stiffness in CKD [17]. As such, the current assessment of the CKD-MBD cardiovascular axis is imperfect and there is potential for biomarkers to contribute.

\section{Emerging Biomarkers}

Calcium, phosphate and parathyroid hormone are used in clinical practice to assess the CKD-MBD axis. There are numerous other biomarkers now available that have been related to the development and progression of CKD-MBD. There are an increasing number of studies that show varying utility of different biomarkers in relation to the outcomes of progression, cardiovascular events and death in CKD. However, many of these are association and not outcome studies and may be confounded by a lack of understanding of the biological actions and mutual interactions of these biomarkers.

Whether novel biomarkers related to CKD-MBD have the potential to enhance the risk stratification or clinical management of the CKD patient over and above traditional parameters and assessment tools needs to be considered before these markers can be adopted in clinical practice.

This review discusses novel biomarkers pertinent to the CKD-MBD and cardiovascular interface, first briefly describing their pathological associations and then the evidence for their usefulness in relation to important clinical endpoints. Serum markers that are already in use in clinical practice, for example calcium, phosphate, alkaline phosphatase and parathyroid hormone $(\mathrm{PTH})$, will not be discussed.

\section{Biological Actions of CKD-MBD Biomarkers (fig. 1)}

\section{Promoters of Calcification in CKD \\ Osteoprotegerin}

Osteoprotegerin (OPG) is a natural inhibitor of calcification, it prevents the terminal differentiation and boneresorbing action of osteoclasts [18]. A rapid development of arterial calcification and osteoporosis is seen in OPG knockout mice [19]. However, in CKD, elevated OPG levels are observed and these have been associated with aortic stiffness and markers of cardiovascular dysfunction such as raised serum troponin $\mathrm{T}$ (TnT) levels [20].

A positive association between OPG and development of arterial calcification exists in CKD. OPG binds to receptor activator of nuclear factor B ligand (RANKL) to inhibit osteoclastogenesis. An increased OPG to RANKL ratio is observed in a low bone turnover state and correlates with increased arterial calcification in $\operatorname{CKD}[21,22]$.

\section{Osteocalcin}

Osteocalcin is a promoter of calcification secreted by osteoblasts. It has been located in atherosclerotic plaques and areas of calcification within vessels [23]. Osteocalcin may also be involved in insulin receptor expression in the metabolic syndrome [24].

\section{Inhibitors of Arterial Calcification in CKD}

Fetuin-A

Fetuin-A is synthesized in the liver and acts as an inhibitor of vascular calcification. Decreased levels are observed among CKD patients and are associated with the development of vascular calcification. Fetuin-A inhibits 
activation of insulin receptors; elevated levels are associated with diabetes and insulin resistance [25]. Thus, fetuin-A activity may dichotomize into an increased risk for atherosclerosis and insulin resistance at high levels and risk for arterial calcification at low levels.

\section{Matrix-Gla Protein}

Matrix-Gla protein (MGP) is a potent inhibitor of calcification, preventing osteoblastic differentiation of vascular smooth muscle cells $[17,26]$. MGP is produced by osteoclasts, chondrocytes and the smooth muscle cells of the arterial media. Different forms of MGP appear to have differing actions. In physiological processes, MGP undergoes vitamin $\mathrm{K}$-dependent $\gamma$-glutamyl carboxylation, its carboxylated form is found in normal vessels and forms circulating complexes with fetuin-A [27]. The non-carboxylated form is present locally in areas of arterial calcification [28]. In mice that lack MGP, accelerated arterial calcification ensues and early death occurs due to extensive arterial calcification and vessel rupture [29].

\section{Osteopontin}

Osteopontin is expressed in mineralized tissues where it acts as an inhibitor of calcification. It is not present in normal vessels but may be expressed in calcified and atherosclerotic vasculature [30].

\section{Other Factors}

Fibroblast Growth Factor-23

Fibroblast growth factor-23 (FGF-23) is a 'phosphatonin' secreted by osteoblasts in response to an oral phosphate load and/or elevated levels of 1,25-dihydroxyvitamin D. It is believed to play a role in phosphate homeostasis, particularly preventing hyperphosphataemia by promoting phosphaturia and reducing renal production of 1,25-dihydroxyvitamin D [31]. Levels among CKD patients are higher than in the general population and are further elevated in the dialysis population [32]. FGF-23 levels correlate with serum phosphate, PTH and calcium [33]. It is postulated that these changes are a compensatory attempt to maintain normal phosphate balance in CKD [34]. It is thought that in advanced CKD, the capacity of FGF-23 to reduce phosphate levels is exceeded. Increasing FGF-23 levels then exhibit pathological effects, including promotion of more rapid progression of renal functional decline and the development of LVH [35].

Klotho

Klotho is a transmembrane protein, highly expressed in the kidney. It acts as a co-receptor for FGF-23 and is thus involved in the promotion of phosphaturia and reduction of arterial calcification. Secretion of the extracellular domain of klotho enables it to function as a humoral factor, promoting phosphaturia [36] and reducing phosphate uptake by vascular smooth muscle cells [37]. Animal studies have shown severe arterial calcification in klotho-deficient mice with CKD. In cross-sectional analysis, klotho levels in the kidney, serum and urine fall as CKD advances [37]. In a study of 312 patients with CKD stages 2-4 followed up for $2.2 \pm 0.8$ years, Seiler et al. [38] found no association between plasma klotho levels and progression to ESRD or death, although potential confounding by vitamin $\mathrm{D}$ and the lack of a control group caused some to question the validity of these results [39]. Further mechanistic studies, particularly examining the relationship between serum levels and tissue expression, and large-scale epidemiological studies are needed to answer these questions. Klotho has potential to be an early sensitive biomarker in CKD-MBD and there may be potential therapeutic benefit from preservation of klotho.

\section{Vitamin D}

The kidney is central to vitamin D metabolism, converting 25-hydroxy- to 1,25-dihydroxyvitamin $\mathrm{D}$, its active form. Vitamin D has a beneficial effect on cardiac contractility, vascular tone and overall cardiac function [40]. Vitamin D deficiency is associated with an increased risk for cardiovascular disease, hypertension and diabetes; it is common in the general population and deficiency rates are significantly higher among CKD patients [41]. Hypervitaminosis D is associated with accelerated renal decline; however, it is likely that this is the result of hypercalcaemia [42]. Although vitamin D does not appear to initiate arterial calcification, hypercalcaemia and hyperphosphataemia induced by high vitamin $\mathrm{D}$ levels do mediate this process [43], and this has led to conflicting results from studies involving vitamin $\mathrm{D}$.

\section{Predictors of Progression}

Progressive renal functional decline is associated with an increased risk for cardiovascular disease [3]. However, this risk of progression varies widely among people with $\mathrm{CKD}$ and there is therefore much interest in identifying risk factors for progression. Factors that have consistently been identified as determinants of progression in epidemiological studies include urine protein excretion and elevated mean arterial pressure 
[44-46], but additional factors that would improve risk prediction or identify new therapeutic targets are required.

The Mild to Moderate Kidney Disease (MMKD) study group looked at factors influencing CKD progression, to a composite endpoint of doubling of serum creatinine or end-stage renal disease (ESRD) in 227 non-diabetic CKD patients. Elevated levels of intact and C-terminal FGF-23 were associated with lower GFR at baseline $(\mathrm{p}<0.001)$. FGF-23 was associated with progression of CKD when adjusted for age, gender, GFR, proteinuria, $\mathrm{PTH}$, calcium and phosphate [47]. Similar findings were observed in 3,879 patients from the Chronic Renal Insufficiency Cohort (CRIC); FGF-23 levels were associated with a lower estimated GFR at baseline. Furthermore, changes in FGF23 were found to occur before PTH and serum phosphate levels increased in CKD [48].

Reduced serum levels of klotho, the renal co-receptor for FGF-23, have been associated with CKD and ageing [37]. In an observational study of 243 CKD patients, klotho levels were reduced in CKD and associated with the composite outcome of progression (defined as doubling serum creatinine or ESRD requiring renal replacement therapy) or death [49] suggesting klotho may be a useful marker of progression in CKD.

Ravani et al. [50] studied 168 patients with CKD stages 2-5 who were followed for a mean period of 48 months (range 1.5-72). Vitamin D deficiency was common and increased with level of renal dysfunction. $25 \%$ of those with CKD stage 2 and $56 \%$ of those with stage 5 were deficient in 25 -hydroxyvitamin $\mathrm{D}$ (level $<30 \mathrm{ng} / \mathrm{ml}$ ). When treated as a categorical variable, low levels of 25-hydroxyvitamin $\mathrm{D}$ were associated with risk for death $(\mathrm{p}<$ 0.001) and ESRD. Although there was no matched healthy cohort and there were many potential co-founders such as calcium and phosphate balance, serum PTH, FGF-23 and therapy, these results suggest that vitamin $\mathrm{D}$ has potential to be a marker of progression and cardiovascular risk in CKD.

\section{Summary}

Although there is encouraging data regarding the ability of CKD-MBD biomarkers to aid in the prediction of progression, these are largely from association studies. There is little information to add to the understanding of mechanisms of progression and the interaction of varying risk factors, which limits the current added value of CKD-MBD biomarkers in this area.

\section{Biomarkers of CKD-MBD and Arterial Calcification/ Vascular Stiffness}

Arterial calcification and vessel hypertrophy are important factors in determining vascular stiffness in CKD [12]. Arterial calcification is frequently used as a surrogate endpoint for an increased cardiovascular risk in biomarker studies.

Numerous studies have demonstrated a link between vascular disease and elevated OPG levels. Mesquita et al. [51] followed 77 patients (32 pre-dialysis, 45 haemodialysis) for 2 years. Coronary artery calcification was assessed by CT. Elevations in OPG correlated with the degree of calcification and were predictive of all-cause mortality. In a study looking at osteopontin levels in 36 haemodialysis patients and 35 matched healthy controls, osteopontin levels were higher in the dialysis group and correlated with degree of aortic calcification as assessed by CT [52]. A further observational study of 107 CKD stage 2-5 patients showed uncarboxylated MGP to be associated with increased aortic calcium scores on CT, levels were higher in later stages of CKD but over a median follow-up of $802( \pm 311)$ days were not significantly associated with increased mortality [53].

Ford et al. [54] carried out a 12-month observational study of 73 non-diabetic and 19 diabetic patients with CKD stages 3 and 4 . Fetuin-A levels were measured at baseline and aortic pulse wave velocity (PWV) determined at time zero and 12 months. Fetuin-A levels were lower in the small non-diabetic CKD group. Lower fetuin-A levels were predictive of an increase in PWV over 1 year $(\beta=$ $0.355, \mathrm{p}<0.001)$ as were age and systolic blood pressure. So, although limited by relatively small study numbers and a short period of follow-up, low fetuin-A measurement may be a useful biomarker of increasing arterial stiffness.

A complex inter-relationship between vitamin D, klotho, FGF-23 and osteopontin has been demonstrated in experimental mouse models. CKD-affected mice that underwent oral phosphate loading prior to treatment with active vitamin D (calcitriol) were less likely to develop aortic calcification than mice that did not receive vitamin D following phosphate loading. Furthermore, vitamin D was observed to increase klotho secretion, promote phosphaturia, increase osteopontin expression and paradoxically reduce FGF-23 independent of PTH and calcium [55]. In a study of 140 CKD stage 2-5 patients, low 25-hydroxyvitamin D levels were independently associated with all-cause mortality at 1 year. However, there was no association between 25 -hydroxyvitamin $\mathrm{D}$ levels and baseline coronary artery calcium scores or arterial stiffness determined by PWV [56]. These studies provide information 
about the pathophysiological effects of vitamin $\mathrm{D}$, the inter-relationship with other calcification co-factors and the potential benefits of vitamin $\mathrm{D}$ therapy, but it is less clear how endogenous vitamin D levels could translate into useful biomarkers of arterial calcification in CKD-MBD.

Studies examining the relationship between FGF-23 and arterial calcification have yielded conflicting results. In a study of 162 pre-dialysis patients and 58 controls with preserved renal function, coronary artery calcium scores were measured by CT in the CKD cohort. The association between FGF-23 and coronary artery calcification was not statistically significant $(\mathrm{p}=0.38)$ [57]. In contrast, Desjardins et al. [58] did observe an association between FGF-23 and elevated aortic and coronary calcium scores in a cohort of $142 \mathrm{CKD}$ stage 2-5 patients but no association between FGF-23 levels and PWV or bone mineral density. Levels of FGF-23 were again observed to increase before serum phosphate in early-stage CKD. Ford et al. [20] were unable to demonstrate an association between FGF-23 and PWV in 200 CKD stage 3-4 patients, although it was associated with increased levels of high-sensitivity TnT. Both FGF-23 and fetuin-A were correlated with baseline atherosclerosis scores on angiography in CKD stages 1-3 [59]. Scialla et al. [60] found no association between FGF-23 levels and coronary artery calcification scores in 1,501 CKD patients recruited from the CRIC study group. Furthermore, elevated FGF-23 levels did not induce arterial calcification in vitro. The results of this study are compelling as it combines observed associations with mechanistic data. The fact that most other studies are purely observational and open to confounding by factors such as serum phosphate levels, small study numbers, variations in stage of CKD and primary disease may account for their conflicting results.

\section{Summary}

Many CKD-MBD biomarkers are associated with arterial calcification and vascular stiffness. It is not clear whether these biomarkers can predict the development of calcification in its early stages and it is even less clear whether therapeutic intervention on the basis of these biomarkers could alter its clinical course.

\section{Biomarkers of CKD-MBD and Cardiovascular Events and Death}

Cardiovascular disease is common among CKD patients and its aetiology is complex. In clinical practice, assessment of traditional risk factors is used to determine the risk for cardiovascular disease and direct risk reduction therapies. Having recognized that arterial calcification and factors such as inflammation are important determinants of cardiovascular disease in CKD, there is potential for biomarkers associated with these processes to aid in the determination of risk for death and cardiovascular events in CKD-MBD.

Studies of fetuin-A in relation to mortality have shown conflicting results. In 822 patients with CKD stages 3-4 selected from the Modification of Diet in Renal Disease (MDRD) cohort, fetuin-A levels were not associated with cardiovascular or all-cause mortality [61], whereas in a cohort of 987 incident dialysis patients followed for a median of 2.8 years, an increase in baseline fetuin-A of 0.1 $\mathrm{g} / \mathrm{l}$ was associated with a hazard ratio (HR) of 0.87 for allcause mortality (95\% CI $0.80-0.93, \mathrm{p}<0.0001)$ and less significantly an HR for cardiovascular mortality of 0.9 (95\% CI 0.81-1, $\mathrm{p}=0.09$ ) [62]. Whether the discrepancies are due to threshold levels of fetuin-A not having been reached or differences in study group demographics is not clear. Further studies relating to cardiovascular outcomes and the pathophysiological mechanisms of action of this marker are needed.

In the haemodialysis population, increased FGF-23 levels are associated with an increased risk for cardiovascular mortality. In a prospective observational cohort of 219 maintenance haemodialysis patients, FGF-23 levels $>8,400 \mathrm{RU} / \mathrm{ml}$ were associated with an increased mortality at 2 years, with an HR for death of 2.5 (CI 1.3-5, p = 0.007 ) [63]. In a nested case-control study of 400 haemodialysis patients, median baseline FGF-23 levels were $2,260 \mathrm{RU} / \mathrm{ml}$ in the 200 patients who died in comparison to $1,406 \mathrm{RU} / \mathrm{ml}$ in the survivors; this difference was significant $(\mathrm{p}<0.001)$ [64].

There is interest in the pathophysiological mechanisms to explain the increased risk for death observed among those with elevated FGF-23 levels. Studies in mice have demonstrated a causal role for FGF-23 in the development of LVH that is independent of klotho [65]. Clinical studies have added to the evidence from animal models. Gutiérrez et al. [57] measured left ventricular mass by echocardiography in 162 pre-dialysis CKD patients and 58 subjects with preserved kidney function. Coronary artery calcium scores were also measured by CT in the CKD cohort. Elevated FGF-23 levels were universally associated with increased left ventricular mass and LVH even after adjustment for blood pressure and the presence of diabetes, with the association greatest among CKD patients. A 5\% increase in left ventricular mass was observed for each 1-SD increase in log-transformed FGF-23. Al- 
Table 1. Summary of outcome studies relating to CKD-MBD biomarkers

\begin{tabular}{|c|c|c|c|c|c|c|c|}
\hline $\begin{array}{l}\text { Reference } \\
\text { (first } \\
\text { author) }\end{array}$ & Biomarker & Population & Follow-up & Type & Patients, $\mathrm{n}$ & Outcome & Clinical endpoints \\
\hline $\begin{array}{l}\text { Isakova } \\
{[32]}\end{array}$ & FGF-23 & $\begin{array}{l}\text { CKD stages } \\
2-4 \text { (CRIC } \\
\text { cohort) }\end{array}$ & $3-5$ years & $\begin{array}{l}\text { prospective } \\
\text { cohort study }\end{array}$ & 3,879 & $\begin{array}{l}\text { FGF- } 23 \text { associated with } \\
\text { increased risk for death; } \\
\text { associated with increased } \\
\text { risk for progression in those } \\
\text { with eGFR }>30 \mathrm{ml} / \mathrm{min}\end{array}$ & $\begin{array}{l}\text { all-cause mortality } \\
\text { progression to ESRF (defined } \\
\text { as initiation of dialysis or } \\
\text { transplantation) }\end{array}$ \\
\hline $\begin{array}{l}\text { Fliser } \\
{[47]}\end{array}$ & FGF-23 & $\begin{array}{l}\text { non-diabetic } \\
\text { CKD stages } \\
2-5 \text { (MMKD } \\
\text { cohort) }\end{array}$ & $\begin{array}{l}\text { median } \\
53 \text { months }\end{array}$ & $\begin{array}{l}\text { prospective } \\
\text { cohort study }\end{array}$ & 177 & $\begin{array}{l}\text { FGF- } 23 \text { predicted } \\
\text { progression of CKD }\end{array}$ & $\begin{array}{l}\text { progression; doubling of } \\
\text { baseline creatinine or ESRF }\end{array}$ \\
\hline $\begin{array}{l}\text { Ärnlöv } \\
{[73]}\end{array}$ & FGF-23 & $\begin{array}{l}727 \text { adult } \\
\text { males (ULSAM } \\
\text { study) }\end{array}$ & $\begin{array}{l}\text { median } \\
9.7 \text { years }\end{array}$ & $\begin{array}{l}\text { longitudinal } \\
\text { population } \\
\text { cohort }\end{array}$ & 727 & $\begin{array}{l}\text { FGF- } 23 \text { associated with CV } \\
\text { mortality in eGFR } \\
<60 \mathrm{ml} / \mathrm{min} \text { group }\end{array}$ & $\begin{array}{l}\text { cardiovascular and all-cause } \\
\text { mortality }\end{array}$ \\
\hline $\begin{array}{l}\text { Gutiérrez } \\
{[64]}\end{array}$ & FGF-23 & $\begin{array}{l}\text { incident } \\
\text { haemodialysis } \\
\text { patients }\end{array}$ & 1 year & $\begin{array}{l}\text { nested case- } \\
\text { control study; } \\
200 \text { survivors, } \\
200 \text { deaths }\end{array}$ & 400 & $\begin{array}{l}\text { FGF-23 associated with } \\
\text { increased mortality }\end{array}$ & all-cause mortality \\
\hline $\begin{array}{l}\text { Kanbay } \\
{[59]}\end{array}$ & $\begin{array}{l}\text { FGF-23/ } \\
\text { fetuin-A }\end{array}$ & $\begin{array}{l}\text { CKD stages } \\
1-3\end{array}$ & baseline & $\begin{array}{l}\text { cross-sectional } \\
\text { study }\end{array}$ & 177 & $\begin{array}{l}\text { fetuin-A and FGF-23 } \\
\text { correlated with Gensini } \\
\text { score for CAD on } \\
\text { angiography }\end{array}$ & $\begin{array}{l}\text { severity of coronary } \\
\text { atherosclerosis on angiography }\end{array}$ \\
\hline $\begin{array}{l}\text { Seiler } \\
{[74]}\end{array}$ & FGF-23 & $\begin{array}{l}\text { CKD stages } \\
2-5\end{array}$ & 4.8 years & $\begin{array}{l}\text { prospective } \\
\text { cohort study }\end{array}$ & 149 & $\begin{array}{l}\text { FGF-23 predictive of } \\
\text { cardiovascular events }\end{array}$ & $\begin{array}{l}\text { all-cause mortality; } \\
\text { cardiovascular events: MI, } \\
\text { angioplasty, CABG, CVA, } \\
\text { carotid endartectomy of } \\
\text { stenting, non-traumatic } \\
\text { amputation of lower limb or } \\
\text { PVD treated by surgery, } \\
\text { angioplasty or stenting }\end{array}$ \\
\hline $\begin{array}{l}\text { Scialla } \\
{[60]}\end{array}$ & FGF-23 & $\begin{array}{l}\text { CKD stages } \\
2-4\end{array}$ & 376 days & $\begin{array}{l}\text { prospective } \\
\text { cohort study }\end{array}$ & 1,501 & $\begin{array}{l}\text { baseline FGF- } 23 \text { not } \\
\text { associated with calcification } \\
\text { scores }\end{array}$ & $\begin{array}{l}\text { baseline coronary artery } \\
\text { calcium scores on CT }\end{array}$ \\
\hline $\begin{array}{l}\text { Desjardins } \\
{[58]}\end{array}$ & FGF-23 & $\begin{array}{l}\text { CKD stages } \\
2-5\end{array}$ & baseline & $\begin{array}{l}\text { prospective } \\
\text { cohort study }\end{array}$ & 142 & $\begin{array}{l}\text { FGF-23 associated with } \\
\text { calcification scores but not } \\
\text { PWV }\end{array}$ & $\begin{array}{l}\text { baseline aortic and coronary } \\
\text { calcium scores on CT and } \\
\text { PWV }\end{array}$ \\
\hline $\begin{array}{l}\text { Ford } \\
{[20]}\end{array}$ & $\begin{array}{l}\text { FGF-23/ } \\
\text { OPG }\end{array}$ & $\begin{array}{l}\text { CKD stages } \\
3-4\end{array}$ & baseline & $\begin{array}{l}\text { prospective } \\
\text { cohort study }\end{array}$ & 200 & $\begin{array}{l}\text { OPG associated with } \\
\text { increased aortic stiffness }\end{array}$ & $\begin{array}{l}\text { change in aortic pulse wave } \\
\text { velocity }\end{array}$ \\
\hline $\begin{array}{l}\text { Sigrist } \\
{[75]}\end{array}$ & OPG & $\begin{array}{l}\text { CKD 4, } \\
\text { haemodialysis } \\
\text { and peritoneal } \\
\text { dialysis patients }\end{array}$ & 40 months & $\begin{array}{l}\text { prospective } \\
\text { cohort study }\end{array}$ & 134 & $\begin{array}{l}\text { OPG associated with } \\
\text { negative outcome/ } \\
\text { increased risk for death }\end{array}$ & all-cause mortality \\
\hline $\begin{array}{l}\text { Mesquita } \\
\text { [51] }\end{array}$ & OPG & $\begin{array}{l}\text { pre-dialysis } \\
\text { CKD and } \\
\text { haemodialysis } \\
\text { patients }\end{array}$ & 2 years & $\begin{array}{l}\text { prospective } \\
\text { cohort study }\end{array}$ & 77 & $\begin{array}{l}\text { OPG independent predictor } \\
\text { of mortality in CKD group }\end{array}$ & $\begin{array}{l}\text { all-cause mortality } \\
\text { coronary artery calcium score }\end{array}$ \\
\hline $\begin{array}{l}\text { Ford } \\
{[54]}\end{array}$ & fetuin-A & $\begin{array}{l}\text { CKD stages } \\
3-4\end{array}$ & 1 year & $\begin{array}{l}\text { prospective } \\
\text { cohort study }\end{array}$ & 92 & $\begin{array}{l}\text { in non-diabetic patients } \\
\text { fetuin-A associated with } \\
\text { progressive arterial stiffness }\end{array}$ & $\begin{array}{l}\text { change in aortic pulse wave } \\
\text { velocity }\end{array}$ \\
\hline $\begin{array}{l}\text { Ix } \\
{[61]}\end{array}$ & fetuin-A & $\begin{array}{l}\text { CKD stages } \\
3-4 \text { patients } \\
\text { (MDRD group) }\end{array}$ & baseline & $\begin{array}{l}\text { observational } \\
\text { study }\end{array}$ & 822 & $\begin{array}{l}\text { fetuin-A not related to } \\
\text { mortality }\end{array}$ & $\begin{array}{l}\text { all-cause and cardiovascular } \\
\text { mortality }\end{array}$ \\
\hline
\end{tabular}


Table 1 (continued)

\begin{tabular}{|c|c|c|c|c|c|c|c|}
\hline $\begin{array}{l}\text { Reference } \\
\text { (first } \\
\text { author) }\end{array}$ & Biomarker & Population & Follow-up & Type & Patients, $\mathrm{n}$ & Outcome & Clinical endpoints \\
\hline $\begin{array}{l}\text { Kanazawa } \\
{[24]}\end{array}$ & osteocalcin & $\begin{array}{l}\text { type } 2 \text { diabetics, } \\
\text { normal renal } \\
\text { function }\end{array}$ & baseline & $\begin{array}{l}\text { prospective } \\
\text { cohort study }\end{array}$ & 328 & $\begin{array}{l}\text { osteocalcin associated with } \\
\text { increased adiponectin, fat } \\
\text { mass and atherosclerotic } \\
\text { parameters }\end{array}$ & $\begin{array}{l}\text { change in aortic pulse wave } \\
\text { velocity, carotid intima-media } \\
\text { thickness assessed by USS and } \\
\text { fat mass on X-ray }\end{array}$ \\
\hline $\begin{array}{l}\text { Nitta } \\
{[52]}\end{array}$ & osteopontin & $\begin{array}{l}\text { haemodialysis } \\
\text { patients }\end{array}$ & baseline & $\begin{array}{l}\text { prospective } \\
\text { longitudinal } \\
\text { study }\end{array}$ & $\begin{array}{l}71(36 \\
\text { dialysis, } \\
35 \text { healthy } \\
\text { controls) }\end{array}$ & $\begin{array}{l}\text { osteopontin associated with } \\
\text { increased aortic } \\
\text { calcification }\end{array}$ & $\begin{array}{l}\text { baseline osteopontin in both } \\
\text { groups; aortic calcification on } \\
\text { CT in haemodialysis group }\end{array}$ \\
\hline $\begin{array}{l}\text { Barreto } \\
{[56]}\end{array}$ & vitamin $\mathrm{D}$ & $\begin{array}{l}\text { CKD stages } \\
2-5\end{array}$ & 605 days & $\begin{array}{l}\text { prospective } \\
\text { cohort study }\end{array}$ & 140 & $\begin{array}{l}\text { vitamin D deficiency/ } \\
\text { insufficiency independently } \\
\text { affected survival }\end{array}$ & all-cause mortality \\
\hline $\begin{array}{l}\text { Teng } \\
\text { [68] }\end{array}$ & vitamin D & $\begin{array}{l}\text { haemodialysis } \\
\text { patients }\end{array}$ & 2 years & $\begin{array}{l}\text { historical } \\
\text { cohort study }\end{array}$ & 51,037 & $\begin{array}{l}\text { vitamin D therapy } \\
\text { associated with increased } \\
\text { survival }\end{array}$ & all-cause mortality \\
\hline $\begin{array}{l}\text { Wolf } \\
\text { [67] }\end{array}$ & vitamin $\mathrm{D}$ & $\begin{array}{l}\text { incident } \\
\text { haemodialysis } \\
\text { patients }\end{array}$ & 90 days & $\begin{array}{l}\text { nested case } \\
\text { control study }\end{array}$ & 925 & $\begin{array}{l}\text { vitamin D deficiency } \\
\text { associated with increased } \\
\text { mortality }\end{array}$ & all-cause mortality \\
\hline
\end{tabular}

ULSAM = Uppsala longitudinal study of adult men; $\mathrm{CAD}=$ coronary artery disease; $\mathrm{MI}=$ myocardial infarction; $\mathrm{CABG}=$ coronary artery bypass grafting; CVA = cerebrovascular accident; PVD = peripheral vascular disease; LVSD = left ventricular systolic dysfunction; HS-cTNT = high-sensitivity cardiac troponin T; HS-cTNI = high-sensitivity cardiac troponin I; LVMI = left ventricular mass index; CAC = coronary artery calcium.

though the highest tertile of FGF-23 was associated with a 2.4-fold increase in risk for coronary artery calcification (95\% CI 1.1-5.5), this was no longer significant after multivariable adjustment. FGF-23 appears to be predictive of cardiovascular events in patients with CKD stages 2-5 [66]. The association between FGF-23 and risk for death appears to exist even in early CKD, before traditional CKD-MBD markers become elevated. FGF-23 has potential to be used in clinical practice in the assessment of cardiovascular risk.

Other biomarkers may be associated with mortality. In a study of 825 incident haemodialysis patients, untreated vitamin $\mathrm{D}$ deficiency was associated with an increased risk for death at 90 days [67]. A further observational study of 50,987 incident haemodialysis patients demonstrated a $20 \%$ survival advantage after 90 days in the 37,123 patients who received vitamin D (HR 0.80, 95\% CI $0.76-0.83, \mathrm{p}<0.001)$ [68]. Sigrist et al. $[14,75]$ demonstrated an association between raised OPG levels and allcause mortality in 134 dialysis and CKD 4 patients followed for 40 months.

Troponin is associated with coronary artery disease and LVH. Smith et al. [69] examined the association between FGF-23, LVH and troponin in a group of 153 stable patients with CKD 3-4. Elevated FGF-23 levels were associated with elevated high-sensitivity cardiac troponin I 
and T (cTNI and cTNT), although the association was weaker when adjusted for left ventricular mass. Other studies have shown cTNT to be predictive of cardiovascular events and overall survival in the CKD population [70-72].

\section{Summary}

Cardiovascular disease is highly prevalent in CKD. Using biomarkers to predict the risk for cardiovascular events and death poses many challenges. Many of the studies looking at biomarkers in relation to cardiovascular endpoints are association studies. There is a paucity of data to demonstrate clear pathophysiological links between biomarkers and these endpoints. FGF-23 is an obvious therapeutic target for cardiovascular risk reduction in CKD, given its causal role in LVH, but not all biomarkers fulfil this brief (table 1).

\section{Conclusion}

The biomarkers discussed in this review provide varied information about arterial calcification, cardiac function and risk for progression in CKD-MBD. There are prospects for better vascular risk assessment in patients with advanced CKD, but as yet no single or suite of biomarkers is available for use in the clinical setting. Numerous barriers need to be overcome before CKD-MBD biomarkers can become part of routine clinical practice; many of the studies performed to date have been small association studies, carried out on select patient groups. Large-scale epidemiological data in diverse populations would enhance understanding of the potential clinical application of these biomarkers. Significantly, understanding of the pathophysiological roles of these biomarkers is patchy and there are many unanswered questions. More in vivo mechanistic studies and a greater understanding of the modes of action and interaction between these biomarkers are needed before they can be reliably applied in clinical practice.

\section{References}

$>1$ Stevens PE, O’Donoghue DJ, De Lusignan S, Van Vlymen J, Klebe B, Middleton R, et al: Chronic kidney disease management in the United Kingdom: NEOERICA project results. Kidney Int 2007;72:92-99.

$>2$ Foley RN, Parfrey PS, Sarnak MJ: Clinical epidemiology of cardiovascular disease in chronic renal disease. Am J Kidney Dis 1998; 32:S112-S119.

3 Go AS, Chertow GM, Fan D, McCulloch CE, Hsu C-Y: Chronic kidney disease and the risks of death, cardiovascular events, and hospitalization. N Engl J Med 2004;351:12961305.

4 Nitta K: Vascular calcification in patients with chronic kidney disease. Ther Apher Dial 2011;15:513-521.

5 Thambyrajah J: Abnormalities of endothelial function in patients with predialysis renal failure. Heart 2000;83:205-209.

6 Menon V, Gul A, Sarnak MJ: Cardiovascular risk factors in chronic kidney disease. Kidney Int 2005;68:1413-1418.

7 Knight EL: Kidney dysfunction, inflammation, and coronary events: a prospective study. J Am Soc Nephrol 2004;15:1897-1903.

8 Stenvinkel P, Ketteler M, Johnson RJ, Lindholm B, Pecoits-Filho R, Riella M, et al: IL-10, IL-6, and TNF- $\alpha$ : central factors in the altered cytokine network of uremia - the good, the bad, and the ugly. Kidney Int 2005;67:12161233.
9 Himmelfarb J, Stenvinkel P, Ikizler TA, Hakim RM: The elephant in uremia: oxidant stress as a unifying concept of cardiovascular disease in uremia. Kidney Int 2002;62:15241538.

10 Garcia-Canton C, Bosch E, Ramirez A, Gonzalez Y, Auyanet I, Guerra R, et al: Vascular calcification and 25-hydroxyvitamin D levels in non-dialysis patients with chronic kidney disease stages 4 and 5. Nephrol Dial Transpl 2011;26:2250-2256.

11 London GM: Arterial media calcification in end-stage renal disease: impact on all-cause and cardiovascular mortality. Nephrol Dial Transpl 2003;18:1731-1740.

12 Guerin AP, Pannier B, Métivier F, Marchais SJ, London GM: Assessment and significance of arterial stiffness in patients with chronic kidney disease. Curr Opin Nephrol Hypertens 2008;17:635-641.

13 Briet M, Bozec E, Laurent S, Fassot C, London GM, Jacquot C, et al: Arterial stiffness and enlargement in mild-to-moderate chronic kidney disease. Kidney Int 2006;69:350-357.

14 Sigrist M, Bungay P, Taal MW, McIntyre CW: Vascular calcification and cardiovascular function in chronic kidney disease. Nephrol Dial Transpl 2006;21:707-714.

15 Schiffrin EL, Lipman ML, Mann JFE: Chronic kidney disease: effects on the cardiovascular system. Circulation 2007;116:85-97.

16 McCullough PA: Why is chronic kidney disease the 'spoiler' for cardiovascular outcomes? J Am Coll Cardiol 2003;41:725-728.
17 Schoppet M, Shroff RC, Hofbauer LC, Shanahan CM: Exploring the biology of vascular calcification in chronic kidney disease: what's circulating? Kidney Int 2007;73:384-390.

-18 Price PA, June HH, Buckley JR, Williamson MK: Osteoprotegerin inhibits artery calcification induced by warfarin and by vitamin $\mathrm{D}$. Arterioscler Thromb Vasc Biol 2001;21: 1610-1616.

19 Bucay N, Sarosi I, Dunstan CR, Morony S, Tarpley J, Capparelli C, et al: Osteoprotegerin-deficient mice develop early onset osteoporosis and arterialcalcification. Genes Dev 1998;12:1260-1268.

-20 Ford ML, Smith ER, Tomlinson LA, Chatterjee PK, Rajkumar C, Holt SG: FGF-23 and osteoprotegerin are independently associated with myocardial damage in chronic kidney disease stages 3 and 4 . Another link between chronic kidney disease-mineral bone disorder and the heart. Nephrol Dial Transpl 2012; 27:727-733.

21 Moe SM, Reslerova M, Ketteler M, O’Neill K, Duan D, Koczman J, et al: Role of calcification inhibitors in the pathogenesis of vascular calcification in chronic kidney disease. Kidney Int 2005;67:2295-2304.

22 Collin-Osdoby P: Regulation of vascular calcification by osteoclast regulatory factors RANKL and osteoprotegerin. Circ Res 2004; 95:1046-1057. 
-23 Bini A, Mann KG, Kudryk BJ, Schoen FJ: Noncollagenous bone matrix proteins, calcification, and thrombosis in carotid artery atherosclerosis. Atheroscler Throm Vasc Biol 1999;19:1852-1861.

24 Kanazawa I, Yamaguchi T, Yamamoto M, Yamauchi M, Kurioka S, Yano S, et al: Serum osteocalcin level is associated with glucose metabolism and atherosclerosis parameters in type 2 diabetes mellitus. J Clin Endocrinol Metab 2008;94:45-49.

25 Singh M, Sharma PK, Garg VK, Mondal SC, Singh AK, Kumar N: Role of fetuin-A in atherosclerosis associated with diabetic patients. J Pharm Pharmacol 2012;64:1703-1708.

-26 Krueger T, Westenfeld R, Ketteler M, Schurgers LJ, Floege J: Vitamin $\mathrm{K}$ deficiency in CKD patients: a modifiable risk factor for vascular calcification? Kidney Int 2009;76:18-22.

-27 Price PA: Discovery of a high molecular weight complex of calcium, phosphate, fetuin, and matrix $\gamma$-carboxyglutamic acid protein in the serum of etidronate-treated rats. J Biol Chem 2001;277:3926-3934.

-28 Schurgers LJ, Teunissen KJF, Knapen MHJ, Kwaijtaal M, van Diest R, Appels A, et al: Novel conformation-specific antibodies against matrix $\gamma$-carboxyglutamic acid (Gla) protein. Atheroscler Throm Vasc Biol 2005;25:16291633.

-29 Luo G, Ducy P, McKee MD, Pinero GJ, Loyer E, Behringer RR, et al: Spontaneous calcification of arteries and cartilage in mice lacking matrix GLA protein. Nature 1997;386:78-81.

30 Mizobuchi M, Towler D, Slatopolsky E: Vascular calcification: the killer of patients with chronic kidney disease. J Am Soc Nephrol 2009;20:1453-1464.

- 31 Liu S: Fibroblast growth factor-23 is a counter-regulatory phosphaturic hormone for vitamin D. J Am Soc Nephrol 2006;17:13051315.

- 32 Isakova T, Xie H, Yang W, Xie D, Anderson $\mathrm{AH}$, Scialla J, et al: Fibroblast growth factor- 23 and risks of mortality and end-stage renal disease in patients with chronic kidney disease. JAMA 2011;305:2432-2439.

- 33 Imanishi Y, Inaba M, Nakatsuka K, Nagasue $\mathrm{K}$, Okuno S, Yoshihara A, et al: FGF-23 in patients with end-stage renal disease on hemodialysis. Kidney Int 2004;65:1943-1946.

34 Kronenberg F: Emerging risk factors and markers of chronic kidney disease progression. Nat Rev Nephrol 2009;5:677-689.

- 35 Jüppner H: Phosphate and FGF-23. Kidney Int 2011;79:S24-S27.

-36 Hu MC, Shi M, Zhang J, Pastor J, Nakatani T, Lanske B, et al: Klotho: a novel phosphaturic substance acting as an autocrine enzyme in the renal proximal tubule. FASEB J 2010;24: 3438-3450.

37 Hu MC, Shi M, Zhang J, Quiñones H, Griffith C, Kuro-o M, et al: Klotho: an elixir of youth for the vasculature? J Am Soc Nephrol 2011; 22:5-7.
Seiler S, Wen M, Roth HJ, Fehrenz M, Flügge $\mathrm{F}$, Herath E, et al: Plasma klotho is not related to kidney function and does not predict adverse outcome in patients with chronic kidney disease. Kidney Int 2012;83:121-128.

-39 Drüeke TB, Massy ZA: Circulating klotho levels: clinical relevance and relationship with tissue klotho expression. Kidney Int 2013;83: 13-15.

40 Archinger SG, Ayus JC: The role of vitamin D in left ventricular hypertrophy and cardiac function. Kidney Int 2005;67:S37-S42.

41 Holick MF: Vitamin D deficiency. N Engl J Med 2007;357:266-281.

42 Christiansen C, Rødbro P, Christensen M, Hartnack B, Transbøl I: Deterioration of renal function during treatment of chronic renal failure with 1,25-dihydroxycholecalciferol. Lancet 1978;312:700-703.

43 Zittermann A, Schleithoff SS, Koerfer R: Vitamin D and vascular calcification. Curr Opin Lipidol 2007; 18:41-46.

44 Hunsicker LG, Adler S, Caggiula A, England BK, Greene T, Kusek JW, et al: Predictors of the progression of renal disease in the Modification of Diet in Renal Disease Study. Kidney Int 1997;51:1908-1919.

45 Remuzzi G, Perico N, Macia M, Ruggenenti P: The role of renin-angiotensin-aldosterone system in the progression of chronic kidney disease. Kidney Int 2005;68:S57-S65.

46 Jafar TH, Stark PC, Schmid CH, Landa M: Progression of chronic kidney disease: the role of blood pressure control, proteinuria, and angiotensin-converting enzyme inhibition: a patient-level met-analysis. Ann Intern Med 2003;139:244-252.

-47 Fliser D, Kollerits B, Neyer U, Ankerst DP, Lhotta K, Lingenhel A, et al: Fibroblast growth factor-23 (FGF-23) predicts progression of chronic kidney disease: the Mild to Moderate Kidney Disease (MMKD) study. J Am Soc Nephrol 2007;18:2600-2608.

48 Isakova T, Wahl P, Vargas GS, Gutiérrez OM, Scialla J, Xie H, et al: Fibroblast growth factor-23 is elevated before parathyroid hormone and phosphate in chronic kidney disease. Kidney Int 2011;79:1370-1378.

-49 Kim HR, Nam BY, Kim DW, Kang MW, Han $\mathrm{J}-\mathrm{H}$, Lee MJ, et al: Circulating a-klotho levels in CKD and relationship to progression. Am J Kidney Dis 2013;61:899-909.

50 Ravani P, Malberti F, Tripepi G, Pecchini P, Cutrupi S, Pizzini P, et al: Vitamin D levels and patient outcome in chronic kidney disease. Kidney Int 2008;75:88-95.

51 Mesquita M, Demulder A, Damry N, Mélot C, Wittersheim E, Willems D, et al: Plasma osteoprotegerin is an independent risk factor for mortality and an early biomarker of coronary vascular calcification in chronic kidney disease. Clin Chem Lab Med 2009;47:339346.

52 Nitta K, Ishizuka T, Horita S, Hayashi T, Ajiro A, Uchida K, et al: Soluble osteopontin and vascular calcification in hemodialysis patients. Nephron 2001;89:455-458.
53 Schurgers LJ, Barreto DV, Barreto FC, Liabeuf S, Renard C, Magdeleyns EJ, et al: The circulating inactive form of matrix Gla protein is a surrogate marker for vascular calcification in chronic kidney disease: a preliminary report. Clin J Am Soc Nephrol 2010;5: 568-575.

54 Ford ML, Tomlinson LA, Smith ER, Rajkumar C, Holt SG: Fetuin-A is an independent determinant of change of aortic stiffness over 1 year in non-diabetic patients with CKD stages 3 and 4. Nephrol Dial Transpl 2010;25: 1853-1858.

55 Lau WL, Leaf EM, Hu MC, Takeno MM, Kuro-o $\mathrm{M}$, Moe OW, et al: Vitamin $\mathrm{D}$ receptor agonists increase klotho and osteopontin while decreasing aortic calcification in mice with chronic kidney disease fed a high phosphate diet. Kidney Int 2012;82:1261-1270.

56 Barreto DV, Barreto FC, Liabeuf S, Temmar M, Boitte F, Choukroun G, et al: Vitamin D affects survival independently of vascular calcification in chronic kidney disease. Clin J Am Soc Nephrol 2009;4:1128-1135.

57 Gutiérrez OM, Januzzi JL, Isakova T, Laliberte K, Smith K, Collerone G, et al: Fibroblast growth factor-23 and left ventricular hypertrophy in chronic kidney disease. Circulation 2009;119:2545-2552.

58 Desjardins L, Liabeuf S, Renard C, Lenglet A, Lemke H-D, Choukroun G, et al: FGF-23 is independently associated with vascular calcification but not bone mineral density in patients at various $\mathrm{CKD}$ stages. Osteoporosis Int 2012;23:2017-2025.

59 Kanbay M, Nicoleta M, Selcoki Y, Ikizek M, Aydin M, Eryonucu B, et al: Fibroblast growth factor-23 and fetuin-A are independent predictors for the coronary artery disease extent in mild chronic kidney disease. Clin J Am Soc Nephrol 2010;5:1780-1786.

60 Scialla JJ, Ling Lau W, Reilly MP, Isakova T, Yang H-Y, Crouthamel MH, et al: Fibroblast growth factor-23 is not associated with and does not induce arterial calcification. Kidney Int 2013;83:1159-1168.

- 61 Ix JH, Shlipak MG, Sarnak MJ, Beck GJ Greene T, Wang X, et al: Fetuin-A is not associated with mortality in chronic kidney disease. Kidney Int 2007;72:1394-1399.

62 Hermans MMH, Brandenburg V, Ketteler M Kooman JP, van der Sande FM, Boeschoten EW, et al.: Association of serum fetuin-A levels with mortality in dialysis patients. Kidney Int 2007;72:202-207.

-63 Jean G, Terrat JC, Vanel T, Hurot JM, Lorriaux $\mathrm{C}$, Mayor B, et al: High levels of serum fibroblast growth factor-23 are associated with increased mortality in long haemodialysis patients. Nephrol Dial Transpl 2009;24:2792-2796.

64 Gutiérrez OM, Mannstadt M, Isakova T, Rauh-Hain JA, Tamez H, Shah A, et al: Fibroblast growth factor-23 and mortality among patients undergoing hemodialysis. N Engl J Med 2008;359:584-592. 
-65 Faul C, Amaral AP, Oskouei B, Hu MC, Sloan A, Isakova T, et al: FGF-23 induces left ventricular hypertrophy. J Clin Invest 2011;121: 4393.

-66 Seiler S, Reichart B, Roth D, Seibert E, Fliser D, Heine GH: FGF-23 and future cardiovascular events in patients with chronic kidney disease before initiation of dialysis treatment. Nephrol Dial Transpl 2010;25:3983-3989.

67 Wolf M, Shah A, Gutiérrez O, Ankers E, Monroy $\mathrm{M}$, Tamez $\mathrm{H}$, et al: Vitamin D levels and early mortality among incident hemodialysis patients. Kidney Int 2007;72:1004-1013.

68 Teng M: Activated injectable vitamin D and hemodialysis survival: a historical cohort study. J Am Soc Nephrol 2005;16:1115-1125.
69 Smith K, DeFilippi C, Isakova T, Gutiérrez OM, Laliberte K, Seliger S, et al: Fibroblast growth factor-23, high-sensitivity cardiac troponin, and left ventricular hypertrophy in CKD. Am J Kidney Dis 2013;61:67-73.

70 Kafetz K: Renal impairment in the elderly: a review. J R Soc Med 1983;76:398.

71 Goicoechea M, Garcia De Vinuesa S, GomezCampdera F, Gutiérrez MJ, Amann R, Blanco $\mathrm{P}$, et al: Clinical significance of cardiac troponin T levels in chronic kidney disease patients: predictive value for cardiovascular risk. Am J Kidney Dis 2004;43:846-853.

72 Apple FS: Multi-biomarker risk stratification of N-terminal pro-B-type natriuretic peptide, high-sensitivity C-reactive protein, and cardiac troponin $\mathrm{T}$ and $\mathrm{I}$ in end-stage renal disease for all-cause death. Clin Chem 2004;50: 2279-2285.
73 Ärnlöv J, Carlsson AC, Sundström J, Ingelsson E, Larsson A, Lind L, et al: Higher fibroblast growth factor- 23 increases the risk of allcause and cardiovascular mortality in the community. Kidney Int 2012;83:160-166.

74 Seiler S, Heine GH, Fliser D: Clinical relevance of FGF-23 in chronic kidney disease. Kidney Int 2009;76:S34-S42.

75 Sigrist MK, Levin A, Er L, McIntyre CW: Elevated osteoprotegerin is associated with allcause mortality in CKD stage 4 and 5 patients in addition to vascular calcification. Nephrol Dial Transpl 2009;24:3157-3162. 